DOI: http://dx.doi.org/10.33387/jiko

\title{
ADOPSI SOCIAL NETWORK ANALYSIS (SNA) DALAM UPAYA MEMBANGUN KETANGGUHAN BENCANA di MASYARAKAT
}

\author{
Irma Yuliana ${ }^{1}$ \\ ${ }^{1}$ Pendidikan Teknik Informatika, Universitas Muhammadiyah Surakarta \\ Email: ${ }^{1}$ irma.yuliana@ums.ac.id
}

(Naskah masuk: 20 September 2019, diterima untuk diterbitkan: 20 Oktober 2019)

\begin{abstract}
Abstrak
Pembangunan ketangguhan bencana merupakan strategi untuk kesiapan bencana. Ketangguhan masyarakat, dalam istilah sosiologis, adalah kemampuan komunitas atau sosial unit untuk menahan guncangan eksternal, seperti bencana, terhadap infrastrukturnya. Peningkatan inkremental dalam ketangguhan dapat secara signifikan meningkatkan kapasitas komunitas untuk mempersiapkan, menanggapi, dan memulihkan diri dari bencana. Kecepatan komunitas dapat memobilisasi dan menggunakan sumber daya selama dan setelah bencana sangat tergantung pada kemampuannya untuk beradaptasi dengan perubahan. Kekuatan jejaring sosial adalah faktor utama yang akan membangunkan dari keterpurukan pasca bencana. SNA (Social Network Analysis) merupakan suatu teknik untuk memetakan dan mengukur relasi dan komunikasi yang terjadi antar manusia, kelompok, organisasi, komputer ataupun entitas yang memproses suatu informasi. SNA dapat diterapkan selama semua fase siklus bencana. Adopsi SNA memiliki potensi untuk merevolusi cara organisasi dan masyarakat berfungsi secara umum, dan mempersiapkan dan menanggapi bencana secara spesifik.
\end{abstract}

Kata kunci: ketangguhan bencana, social network analysis

\section{SOCIAL NETWORK ANALYSIS (SNA) ADOPTION IN EFFORTS TO BUILD DISASTER RESPONSE IN COMMUNITIES}

\begin{abstract}
Disaster resilience development is a strategy for disaster preparedness. Community resilience, in sociological terms, is the ability of a community or social unit to withstand external shocks, such as disasters, against its infrastructure. An incremental increase in resilience can significantly increase the capacity of the community to prepare, respond to, and recover from disasters. The speed at which a community can mobilize and use resources during and after a disaster is very dependent on its ability to adapt to change. The strength of social networking is the main factor that will awaken from the post-disaster slump. SNA (Social Network Analysis) is a technique for mapping and measuring relations and communication that occur between people, groups, organizations, computers or entities that process information. SNA can be applied during all phases of the disaster cycle. The adoption of SNA has the potential to revolutionize the way organizations and communities function in general, and to prepare and respond to disasters specifically.
\end{abstract}

Keywords: Disaster resilience, social network analysis

\section{PENDAHULUAN}

Ketangguhan masyarakat, dalam istilah sosiologis, adalah kemampuan komunitas atau sosial unit untuk menahan guncangan eksternal, seperti bencana, terhadap infrastrukturnya. Ketangguhan masyarakat muncul dari kemampuan komunitas untuk beradaptasi dengan stres dan kembali ke fungsi yang sehat. Kecepatan komunitas dapat memobilisasi dan menggunakan sumber daya selama dan setelah bencana sangat tergantung pada kemampuannya untuk beradaptasi dengan perubahan. Kekuatan jaringan sosial adalah faktor penting. Membangun ketahanan masyarakat adalah sebuah proses yang mengembangkan kapasitas yang memungkinkan masyarakat beradaptasi. Pembangunan ketahanan bencana dapat dianggap sebagai strategi untuk kesiapan bencana. Peningkatan secara bertahap dalam ketahanan dapat secara signifikan meningkatkan kapasitas komunitas untuk mempersiapkan, menanggapi, dan memulihkan diri dari bencana. Namun, sebagaimana komunitas dapat 
berubah seiring waktu, respons komunitas terhadap bencana dapat berubah seiring waktu. Bencana yang berdampak kecil pada masyarakat pada satu waktu dapat berdampak buruk pada waktu yang lain. Sebuah pemahaman tentang sifat dinamis dari ketahanan sangat penting untuk perencanaan yang baik. Keberhasilan membangun ketahanan bergantung pada pengurangan risiko kepada individu dan komunitas. Ini juga tergantung pada pengembangan program intervensi jangka panjang dirancang untuk mengubah atau memperbaiki kondisi dan perilaku di masyarakat, membuatnya tahan terhadap stres dan berubah seiring waktu.

SNA (Social Network Analysis) merupakan suatu teknik untuk memetakan dan mengukur relasi dan komunikasi yang terjadi antar manusia, kelompok,organisasi, komputer ataupun entitas yang memproses suatu informasi (Hansen et al. 2012). Aplikasi analisis jejaring sosial dapat diterapkan untuk membangun ketahanan bencana masyarakat. SNA dapat diterapkan selama semua fase siklus bencana. Adopsi SNA memiliki potensi untuk merevolusi cara organisasi dan masyarakat berfungsi secara umum, dan mempersiapkan dan menanggapi bencana secara spesifik. SNA memungkinkan studi sistem manusia yang kompleks melalui visualisasi dan karakterisasi hubungan antara orang, kelompok, dan organisasi. Representasi grafis dari jaringan sosial yang menunjukkan anggota jaringan individu (didefinisikan sebagai node) dan hubungan mereka (didefinisikan sebagai ikatan) bisa menjadi produk dari analisis (lihat Gambar 1).

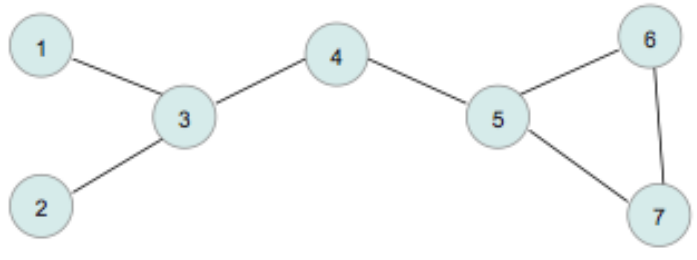

Gambar 1. Node Presentasi

Dampak dari informasi atau kegiatan pada individu dan jaringan secara keseluruhan mungkin dianalisis dan diprediksi untuk berbagai skenario dan opsi. Karena SNA dapat mengungkapkan karakteristik, komposisi, dan struktur jaringan pada waktu tertentu dan dari waktu ke waktu, SNA bisa menjadi alat penting untuk memahami bagaimana bagian dari komunitas bekerja atau dapat bekerja sama untuk merencanakan dan menanggapi bencana. SNA telah digunakan untuk menginformasikan kebijakan di bidang-bidang seperti pencegahan terorisme dan peningkatan kesehatan masyarakat, dan bisa memfasilitasi pengambilan keputusan terkait dengan peningkatan ketahanan terhadap bencana masyarakat.

\section{METODE PENELITIAN}

Network science (ilmu jejaring) mempunyai fokus pada studi terhadap pola koneksi dalam suatu cakupan yang luas dari fenomena fisik dan sosial. Social Network Analysis (SNA) atau Analisis Jejaring Sosial (SNA) awalnya merupakan salah satu aplikasi pengembangan untuk mempelajari relasi dan hubungan antar manusia. Pada perkembangannya metode SNA dapat diterapkan pada berbagai bidang kajian misalnya ilmu antropologi, biologi, ilmu komunikasi, geografi, psikologi, sosial, dan ilmuilmu eksata lainnya seperti matematika, fisika dan kimia. Beberapa penelitian menggunakan metode ini dengan mencermati keterhubungan dan aktivitas pada objek penelitian yang dapat dikelompokkan dalam beberapa bidang berikut ini. Entitas yang terhubung disebut dengan spigot, sebagaimana ditunjukkan pada Gambar 2.

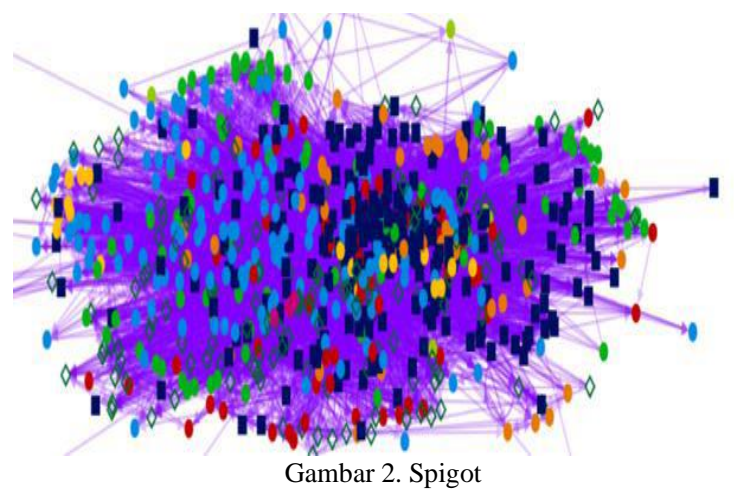

\section{1 Olahraga}

SNA dalam bidang olah raga digunakan untuk mengidentifikasi pola permainan sepak bola pada suatu pertandingan. SNA dibuat berdasarkan berdasarkan pada video yang merekam pertandingan bola antara Korea Selatan melawan Uni Emirat Arab. Hasil skor yang dimenangkan oleh tim Korea Selatan ternyata sesuai dengan analisis menggunakan SNA. Para pemain direpresentasikan sebagai simpul (vertices), operan bola antar pemain merupakan sisi (edges), dan intensitas tendangan umpan didefinisikan sebagai derajat atau bobot (Park and Yilmaz 2010). Semakin banyak bola umpan maka tim semakin solid untuk melakukan penyerangan. Hal ini berbeda dengan tim UEA yang tidak banyak terjadi bola umpan, sehingga tim cenderung bertahan. Pola permainan suatu pertandingan sepakbola dapat dimonitor dengan metode ini, untuk mengevaluasi kekalahan, memetakan kekuatan lawan ataupun kecurangan yang mungkin terjadi. Improvisasi sebagai bentuk adaptasi terhadap pihak lawan lebih banyak dilakukan oleh pemain Korea Selatan. Hal ini dapat diketahui melalui adanya perbedaan antara ground-truth berupa pemetaan posisi dan tugas para pemain oleh pelatih dan kenyataan permainan di lapangan.

\section{2 Kuliner}


Kular dan Menezes menggunaan metode analisis jejaring sosial pada resep masakan di dunia dengan NoR (Network of Recipe). NoR mengkaitkan bahan - bahan masakan dari sajian kuliner yang menjadi ciri khas 15 negara di dunia (Kular, Menezes, and Ribeiro 2011). Budaya dalam sajian kuliner direpresentasikan sebagai resep masakan, yang tersusun atas banyak bahan dasar dan pendukung. Berbagai sajian kuliner dari banyak negara ternyata mempunyai keterhubungan berdasarkan bahan baku yang digunakan, sekaligus hal ini mengungkapkan sejarah latar belakang suatu daerah atau negara sebagai asal muasal masakan tersebut yang juga dipengaruhi oleh budaya negara lain. Namun satu hal yang penting bahwa kemiripan pada bahan dasar yang digunakan terjadi karena substitusi terhadap bahan yang tidak ditemukan pada lokasi geografis yang berbeda.

\section{3 Investigasi kriminilitas}

Pada upaya pencarian pelaku kriminal Shang dan Yuang (Shang and Yuan 2012) menggabungkan dua metode yakni Crime Network Analysis (CAN), sebagai metode manual yang selama ini digunakan dalam investigasi kasus kriminal dan Social Network Analysis (SNA) untuk menentukan aktor kunci dalam jaringan organisasi teroris dengan tiga parameter (relative degree, relative betweenness, relative closeness). Sedangkan untuk bidang yang serupa Tayebi dan Glässer (Tayebi and Glasser 2012) menerapkan teknik deteksi komunitas (community detection) sebagai pengembangan SNA dan penambangan data untuk mengorganisir aktor/ kriminal yang aktif dan serius, beserta aktivitas kelompoknya. Pendekatan dengan analisis blogs diterapkan oleh Yang dan Tobun (Wei and Wen 2011) melalui tahap analisis keterhubungan (link) dan analisis konten (content) untuk memberilan visualisasi informasi yang interaktif dalam mengidentifikasi aksi kriminal dan terorisme.

\section{4 Politik}

Tahun 2006 pertama kalinya blog Parlemen Cina atau CPPCC (Chinese People's Political Consultative Conference) muncul di China. Pada masa ini blog politik mulai naik daun di kalangan netizan Cina. SNA diterapkan guna meneliti relasi antara berbagai macam aktor politik, menemukan opini pemimpin dan anggota utama yang relatif cukup berpengaruh pada komunitas partisipan. Penelitian ini menggunakan software UCINET untuk mengungkapkan struktur politik melalui matrik 42 blog politik yang memiliki relasi. Analisis dilakukan terhadap degree centrality, betweenness centrality, closeness centrality dan analisis komprehensif. Identifikasi anggota penting dapat membantu dalam mengarahkan ide pokok dari blog politik yang terhubung dan juga membuka kemungkinan untuk memprediksi tren perkembangan opini publik dalam kajian politik.

\section{5 Ekonomi}

"Panic buying of salt" adalah kepanikan masyarakat di China pada tahun bulan Maret 2011 untuk membeli garam sebanyak - banyaknya setelah gempa bumi di Jepang yang menyebabkan kebocoran instalasi nuklir Jepang. Rumornya kebocoran ini mencemari lautan yang megandung garam beryodium, sebagai salah satu kebutuhan vital masyarakat. Rumor ini berkembang dari kota- ke kota secara mulut ke mulut dalam waktu singkat. Namun hanya dalam jangka waktu sepuluh hari pemerintah China berhasil meredam gejolak yang sangat berpotensi mengacaukan stabilitas ekonomi di negara tersebut. SNA sangat berperan dalam membangun struktur jaringan darurat dalam kepanikan pasar ini melalui beberapa langkah antara lain (Wei and Wen 2011):

- menentukan simpul jejaring bencana yang merupakan kota - kota yang terkena rumor, media, distributor, masyarakat/ publik dan pemerintah setempat.

- menentukan hubungan/ relasi antar simpul dalam jaringan dengan suatu pemodelan antara lain sebagai relasi kooperatif, relasi superordinat maupun sub-ordinat. Dalam hal ini juga ditentukan relasi yang lemah dan kuat, melalui densitas jaringan, jarak antar simpul, sentralitas dan closeness.

- pengumpulan dan pemrosesan data.

- pembangunan jaringan darurat.

Penelitian ini menunjukkan bahwa berdasarkan pada struktur topologi jejaring sosial, penyebaran informasi selama masa darurat sangat dinamis dengan karakteristik komplek. Topologi tersebut juga menunjukkan kekuatan partisipan, stabilitas dan efektivitas manajemen informasi pada jaringan utama yang secara positif terkorelasi dan terkendali pada akhirnya.

Pada kasus lain, penyalahgunaan atau penyelewengan keuangan dalam suatu perusahaan atau instansi merupakan permasalahan fatal yang berujung pada kejahatan sekaligus kerugian dari sisi perekonomian. Aktivitas yang termasuk dalam tindak pidana ini adalah corruption, asset misappropriation dan fraudulentstatements. Pencegahan terjadinya financial fraud dengan mendeteksi aliran hasil kejahatan berdasarkan perilaku individu dan kelompok dilakukan dengan menggunakan metrik dan metodologi Social NetworkAnalysis (SNA) (Alamsyah and Rahardjo 2013). SNA memodelkan hubungan antar individu pada suatu jaringan sosial tertentu. Pengamatan struktur jaringan model pada SNA dapat dipakai sebagai dasar untuk mendeteksi anomali yang mungkin terjadi pada jaringan dimana financial fraud terjadi, antara lain pada tiga hal berikut

a. frekuensi komunikasi antar individu, 
b. kuantitas komunikasi dua arah antar individu (reciprocal)

c. struktur atau kohesi dari komunitas yang ada didalam jaringan tersebut

Kondisi anomali dinyatakan, jika terlihat komunikasi yang lebih aktif dari biasanya, pola komunikasi yang simetris antar individu dan akan terlihat jelas pada struktur dalam jaringan karena biasanya pelaku kejahatan melakukan komunikasi yang cukup intensif. Selain itu pemantauan terhadap aktor sentral dalam suatu organisasi perlu ditekankan karena berpotensi untuk mempengaruhi aktor lain, lagi pula posisi ini juga cukup cerdik untuk memanipulasi lingkungan karena pengetahuannya yang detil tentang cara kerja organisasi. Pembuktian penelitian ini masih mengalami kendala mengingat dataset sebagai populasi adalah sumber daya vital perusahaan yang bersifat rahasia.

\section{HASIL DAN PEMBAHASAN}

\subsection{Adopsi SNA Dalam Bencana}

Pusat Pendidikan Mitigasi Bencana Universitas Pendidikan Indonesia mendefinisikan mitigasi bencana sebagai rangkaian upaya untuk mengurangi risiko bencana, baik melalui pembangunan fisik maupun mental disertai dengan peningkatan kemampuan menghadapi ancaman bencana. Mitigasi bencana merupakan suatu aktivitas yang berperan sebagai tindakan pengurangan dampak bencana, atau usaha-usaha yang dilakukan untuk megurangi korban ketika bencana terjadi, baik korban jiwa maupun harta. Teknik SNA sangat membantu dalam mitigasi bencana melalui upaya pemetaan terhadap penanganan banjir bandang di Australia pada tahun 2010 - 2011 yaitu di daerah Queensland, New South Wales dan Victoria. Ekstraksi data dari media sosial Twitter digunakan untuk memantau dan menganalisis jejaring yang sedang online pada saat itu. Dari ketiga daerah di atas Queensland paling banyak memiliki pemain aktif dalam jejaring online yang menyebarluaskan informasi penting pada saat dan pasca bencana melanda. Pemain aktif yang dimaksud adalah otoritas lokal yaitu kepolisian setempat, para politisi, sukarelawan media sosial, reporter media, masyarakat dan komunitas peduli bencana. Informasi penting mengenai bencana mencakup wilayah tergenang banjir, jumlah korban, evakuasi, posko pengungsi, distribusi bahan makanan dan obat obatan dan juga terapi pasca bencana. Identifikasi pemain aktif dilakukan melalui degree centrality dari banyak aktor yang terlibat. Rendahnya interaksi daring pada dua wilayah lain, kurang mendukung dalam penyediaan data. Faktor lain yang diharapkan dari penelitian ini (Cheong and It 2011) adalah mengenai : (1)keterlibatan aktor yang dinilai masih kurang karena dari tiga wilayah bencana hanya Queensland yang cukup dinamis dalam pemberitaan melalui media sosial (Twitter) dan; (2)penggalian tulisan (text mining) sekaligus analisisnya untuk mendukung efektivitas media sosial (Twitter) selama masa bencana.

Topik lain yang masih berkaitan dengan mitigasi bencana adalah keterkaitan pada sistem yang komplek dalam Internet of Things (IoT) untuk manajemen bencana. Internet of Things (IoT) adalah sebuah paradigma untuk memperluas manfaat dari konektivitas internet yang tersambung secara terusmenerus, berikut kemampuan remote control, berbagi data, dan sebagainya, termasuk pada benda-benda di dunia fisik. Termasuk dalam penanganan bencana yang melibatkan banyak pihak termasuk manusia, perangkat dan sistem. SNA diterapkan untuk menganalisis interaksi dari banyak pihak tersebut. Aktor yang terlibat termasuk bahan pangan, perangkat elektronik, termasuk benda hidup, yang semuanya tersambung ke jaringan lokal dan global melalui sensor tertanam dan selalu aktif. Pendekatan kolaboratif ini dianalisis melalui SNA guna menentukan inter-relasi yang terjadi antar objek dan propertinya karena manajemen bencana bukanlah sub-sistem tunggal namun reflek yang melibatkan banyak sistem untuk merespon (Zelenkauskaite et al. 2012).

Secara keseluruhan mtode SNA dapat diterapkan dalam banyak bidang, umunya dengan menentukan kepadatan relasi yang terjadi antar individu, menentukan tokoh sentral ataupun aktor aktor penting lainnya. Visualisasi pada dasarnya adalah bagaimana dan di mana cara meletakkan simpul sebagai representasi aktor yang saling berhubungan. SNA yang baik memilik visualisasi yang jelas sehingga mudah dalam pembacaan. Banyak metode dalam visualisasi namun tidak dijelaskan secara detil dan mungkin berbeda satu sama lain sesuai dengan objek penelitian. SNA bukan hanya menganalisis kejadian dalam satu waktu yang sudah terjadi namun juga dapat dimanfaatkan untuk mengarahkan pada penciptaan kondisi yang diinginkan, melalui evaluasi pada kejadian sebelumnya. Teknis detil dari metode ini mencakup banyak hal yang dapat dikaji lebih lanjut, mulai dari menentukan aktor sentral, pengelompokan, membuat visualisasi bahkan memberi informasi rekomendasi.

SNA juga digunakan pada pemetaan komunitas yang merespon peristiwa bencana hutan terbakar di wilayah Indoensia beberapa tahun yang lalu hingga menimbulkan bencana yang lain yaitu asap, yang melanda negara tetangga (Irma Yuliana, P.Insap Santosa, Noor Akhmad 2017). Mitigasi tersebut dilakukan pada saat bencana asap terjadi, pada suatu komunitas online penggiat alam. Hasil penelitian ini mengungkapan adanya beberapa pihak yang secara positif bahkan negative dalam merespon bencana asap tersebut. Beberapa node yang merupakan representasi dari aktor teridentifikasi 10 orang yang cukup aktif. Sepuluh besar yang aktif direprentasikan dalam ukuran node yang lebih besar. Selanjutnya data graf dalam bentuk node dan sisi (edge), akan ditinjau 
lagi untuk mengidentifikasi komunitas di dalam jejaring.

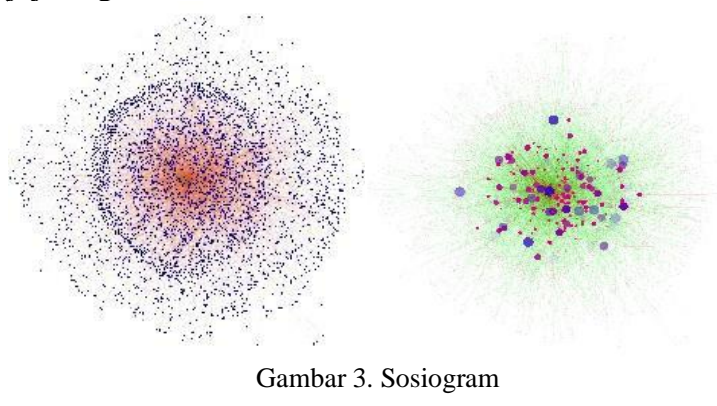

\subsection{Deteksi Komunitas}

Jejaring media sosial merupakan salah satu platform yang menjembatani dunia nyata dan maya. Ratusan juta orang dari seluruh penjuru dunia menggunakan waktunya untuk berbagi, berkomunikasi, berhubungan, berinteraksi dan menciptakan informasi yang bersumber dari pengguna di media sosial. Media sosial menjadi salah satu sumber informasi yang unik karena sifatnya yang noisy, bebas format, bervariasi panjangnya, multimedia dan beberapa saling berhubungan dalam suatu bentuk relasi [34].

Sebuah studi jejaring yang kompleks (complex network), memiliki struktur komunitas. Syaratnya jika simpul pada jejaring dapat dengan mudah dikelompokkan dan saling terhubung secara internal dalam grup. Komunitas daring juga terkenal sebagai groups, cluster atau cohesive subgroups. Pembelajaran komunitas secara luas dilakukan dalam berbagai bidang multidisiplin dan yang paling menonjol adalah keterkaitannya khususnya dengan ilmu sosial dan ilmu komputer (computer science). Penelitian tentang komunitas dalam media sosial dinilai cukup penting dengan beberapa alasan (Missaoui and Sarr n.d.) :

1) Individu seringkali membentuk kelompok berdasarkan kesamaan terhadap suatu hal, dan ketika mempelajari seseorang maka secara tidak langsung juga akan tertarik dengan komunitasnya.

2) Kelompok menyediakan wacana yang luas tentang interaksi penggunanya, dimana sudut pandang seseorang seringkali berubah - ubah tidak menentu.

3) Beberapa tingkah laku hanya dapat diamati dalam sebuah kelompok dan bukan pada level individual. Hal ini dikarenakan tingkah laku individu yang fluktuatif, sedangkan kelompok lebih kokoh untuk berubah.

Pemodelan yang efektif untuk mendeteksi komunitas sebagai relasi yang cukup komplek direpresentasikan dengan simpul sebagai entitas dan sisi sebagai bentuk interaksi atau relasinya. Terdapat banyak penelitian yang menerapkan algoritma tertentu untuk mendeteksi komunitas berdasar pada teori graf. Deteksi komunitas mampu memberikan informasi analisis dan struktur daring, misalnya pada investigasi kriminalitas aksi terorisme (Tayebi and Glasser 2012) diterapkan deteksi komunitas terhadap situs web yang sering dikunjungi tersangka.

Deteksi komunitas sudah dilakukan pada tahun 1977 yang diketahui dari penelitian Zachary's Karate Club (Zachary and Zachary 2009) yaitu sebuah organisasi olah raga universitas. Seiring berjalannya waktu, pada tahun ke-2 organisasi ini mengalami perpecahan internal, yang berakhir salah satu anggota mendirikan perkumpulan sendiri. Zachary melakukan spectral bisection untuk menentukan grup yang terpecah tersebut, dan berprinsip hanya membagi dua bagian dalam graf. Perpecahan tersebut muncul karena kebijakan pengelola yang tidak disetujui oleh anggota, dan Zachary membagi anggota hanya berdasar pada setuju-tidak setuju. Pada ruang lingkup populasi yang besar spectral bisection dinilai tidak efektif dari sisi waktu, sumber daya dan hasil yang kurang memuaskan.

Zachary's Karate Club selanjutnya diteliti oleh Girvan-Newman dengan menggunakan jenis graf sederhana tanpa menyebutkan intensitas (unweighted) dan menerapkan algoritma edgebetweenness yang mengembangkan ide dari SNA melalui sisi keperantaraan untuk menentukan komunitas. Hasil yang didapatkan Girvan- Newman menemukan bahwa struktur komunitas yang didapatkan cukup akurat dibandingkan dengan penelitian awal oleh Zachary dan lebih baik dari pada metode tradisional yang tersusun dengan hierarki dalam bentuk tree berdasarkan edgeindependent (Girvan and Newman 2002). Struktur komunitas yang komplek dipartisi dalam beberapa grup, mempunyai kecenderungan mengelompok secara alamiah, yang ditandai dengan adanya jembatan - jembatan yang menghubungkan antar kelompok tersebut. Jembatan atau bridge inilah yang juga dikenal dengan betweenness centrality.

Adopsi SNA dalam membangun ketangguhan bencana antara lain sebagai :

1) SNA untuk intervensi yang direncanakan.

2) SNA untuk meningkatkan respon pertanggungjawaban dalam waktu

3) SNA untuk menigkatkan kualitas komunikasi antar pihak yang berwenang termasuk, jasa otoritas, relawan.

\section{KESIMPULAN DAN SARAN}

SNA dapat diterapkan dalam analisis komunitas manajemen darurat dan rencana tanggap darurat yang ada di tingkat nasional, negara bagian, dan lokal.

Pada dasarnya masalah pokok yang dihadapi dalam SNA adalah tidak adanya groundtruth (nilai rujukan) umum untuk mengevaluasi hasil akhir. Pada sistem rekomendasi ekstraksi data, kriteria perankingan, kedinamisan data dan evaluasi merupakan faktor yang perlu dicermati. Namun demikian masih perlu banyak dilakukan pengembangan penelitian menggunakan metoda SNA [17]. Penelitian ini 
menerapkan metode SNA yang mengambil data dari media daring facebook untuk mewakili kedinamisan data yang tidak terstruktur. SNA dalam penelitian ini mencakup penentuan fitur - fitur sosiometrik sekaligus visualisasi relasi dalam graf untuk mendapatkan gambaran persebaran pengguna sebagai sumber maupun perantara informasi. Selanjutnya struktur komunitas ditentukan melalui deteksi komunitas dengan suatu pendekatan.

\section{DAFTAR PUSTAKA}

[1] Alamsyah, Andry, and Budi Rahardjo. 2013. "Financial Fraud Detection Using Social Network Analysis." (July).

[2] Cheong, France, and Business It. 2011. "Social Media Data Mining: A Social Network Analysis of Tweets During The Australian 2010 - 2011 Floods."

[3] Girvan, M, and M E J Newman. 2002. "Community Structure in Social and Biological Networks." PNAS 99(12).

[4] Hansen, Derek L. et al. 2012. "Do You Know the Way to SNA?: A Process Model for Analyzing and Visualizing Social Media Network Data." 2012 International Conference on Social Informatics (SocialInformatics): $304-13$. http://ieeexplore.ieee.org/lpdocs/epic03/wrapper .htm?arnumber=6542455 (December 30, 2014).

[5] Irma Yuliana, P.Insap Santosa, Noor Akhmad, Sukirman. 2017. "Finding The Most Important Actor in Online Crowd." IOP 9(1): 533-39.

[6] Kular, Dalwinderjeet Kaur, Ronaldo Menezes, and Eraldo Ribeiro. 2011. "Using Network Analysis to Understand the Relation between Cuisine and Culture." Proceedings of the 2011 IEEE 1st International Network Science Workshop, NSW 2011: 38-45.

[7] Missaoui, Rokia, and Idrissa Sarr. Social Network Analysis - Community Detection and Evolution.

[8] Park, Kyoung-Jin, and Alper Yilmaz. 2010. "Social Network Approach to Analysis of Soccer Game." 2010 20th International Conference on Pattern Recognition: 3935-38. http://ieeexplore.ieee.org/lpdocs/epic03/wrapper .htm?arnumber=5597672 (December 30, 2014).

[9] Shang, Xufeng, and Yubo Yuan. 2012. "Social Network Analysis in Multiple Social Networks Data for Criminal Group Discovery." 2012 International Conference on Cyber-Enabled Distributed Computing and Knowledge Discovery: 27-30. http://ieeexplore.ieee.org/lpdocs/epic03/wrapper .htm?arnumber=6384940 (December 30, 2014).

[10] Tayebi, M. a., and U. Glasser. 2012. "Investigating Organized Crime Groups: A Social Network Analysis Perspective." 2012 IEEE/ACM International Conference on Advances in Social Networks Analysis and Mining: 565-72. http://ieeexplore.ieee.org/lpdocs/epic03/wrapper .htm?arnumber=6425708 (December 30, 2014).

[11] Wei, Kang, and Wen-wu Wen. 2011. "Research on Emergency Information Management Based on the
Social Network Analysis Üü A Case Analysis of Panic Buying of Salt." : 1302-10.

[12] Zachary, Wayne W, and Wayne W Zachary. 2009. "Flow Modelfor Conflict An Information Fission in Small Groups1." 33(4): 452-73.

[13]Zelenkauskaite, Asta, Nik Bessis, Stelios Sotiriadis, and Eleana Asimakopoulou. 2012 "Interconnectedness of Complex Systems of Internet of Things through Social Network Analysis for Disaster Management." 2012 Fourth International Conference on Intelligent Networking and Collaborative Systems: 503-8. http://ieeexplore.ieee.org/lpdocs/epic03/wrapper .htm?arnumber=6337971 (December 29, 2014). 